\title{
Joint survey by Japan and France in South Pacific
}

\section{Tokyo}

JAPAN's Science and Technology Agency and France's IFREMER last week signed an agreement to carry out a joint survey of back-arc basins in the South Pacific using deep-sea submersibles from both countries.

The multi-million dollar project, named STARMER-1, was first proposed last year by Japan and France at a meeting in the Cook Islands of the Committee for Coordination of Joint Prospecting for Mineral Resources in South Pacific Offshore Areas and was warmly welcomed by South Pacific island nations, according to Dr Honza of the Geological Survey of Japan, one of the project scientists. Expected to run for five years, the survey will be joined by scientists from the South Pacific islands, as well as France, Japan and the United States, and comes at a time when Japan, at the urging of the United States, is showing increased interest in this region.

The Kaiyo, a twin-hulled research vessel belonging to the Japan Marine Science and Technology Center of the Science and Technology Agency, will set sail in November to carry out a survey of the North Fiji Basin. The basin lies between the colliding Pacific and Indian plates and has a complex network of spreading ridges on which may be located hydrothermal vents, vent organisms and mineral deposits.

The Kaiyo's multibeam side-scan sonar (SEABEAM) will map the sea floor of the basin, which ranges from 2,000 to $4,000 \mathrm{~m}$ in depth, and hydrographic equipment and a deep-tow vehicle will be used to try to locate hydrothermal vents and suitable sites for the French submersible Nautile to dive to in late 1988 and/or early 1989.

At a later stage, Japan will bring the submersibles Shinkai 2000 (depth range $2,000 \mathrm{~m}$ ) and Shinkai 6000 to the survey area - the latter submersible is due to be built by 1988 and will have a depth range of $6,500 \mathrm{~m}$, simlar to Nautile $(6,000 \mathrm{~m})$. Japan's recently completed Dolphin $3 K$, an unmanned vehicle equipped with manipulator arms, television and CTD (conductivity-temperature-depth meter), will also be let loose to scan and sample the sea floor while tethered to the ship by several kilometres of optical-fibre cable.

Apart from locating vents and associated fauna and mineral deposits, STARMER-1 will aim at elucidating the mechanisms of seafloor spreading in back-arc basins and will also provide an opportunity to study the microplates in the buffer zone between the Indian and Pacific plates, according to Honza.

Marine scientists affiliated with the
Ministry of International Trade and Industry, the Ministry of Education, Science and Culture, and the Environmental Agency, as well as the Science and Technology Agency, will take part in the project. But funding, to be split equally

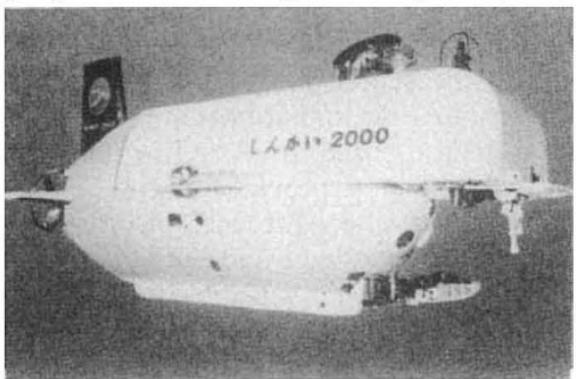

Japanese deep-sea submersible. between Japan and France, will come entirely from the Science and Technology Agency on the Japanese side, and the agency expects to use Y200-300 million (about $\$ 2$ million) out of its special promotion funds for this fiscal year to cover the costs of the Kaiyo cruise in 198788 , according to Masato Chijiya, director of the Ocean Development Division of the agency.

The Ministry of Education, quick to spot an opportunity to save money, has proposed another joint survey with France in 1988, also using the Nautile, as a sequel to the KAIKO project (see Nature 308, 102; 1984). Although independent of STARMER-1 - the proposed survey area of KAIKO-2 is the Nankai Trough off the Pacific coast of Japan - the presence of the Nautile and its mother ship the Nadir in the Pacific in 1988-89 would greatly reduce the costs of KAIKO-2.

David Swinbanks

\section{India says Union Carbide must pay compensation for Bhopal}

\section{New Delhi}

INDIAN officials say that Union Carbide cannot avoid paying hefty compensation to victims of the Bhopal gas tragedy by trying to prove that the accident was caused by sabotage. Sources said that the US company is liable to pay irrespective of how the accident occurred.

The officials were reacting to a report in the New York Times on 23 June saying that Union Carbide has found "new witnesses, documents and scientific evidence" proving that the 1984 leak of toxic methyl isocyanate (MIC) gas was caused by sabotage by a company employee. They said the sabotage theory is untenable and alleged that Carbide might be fabricating evidence. "In any case", said one official, "it is good for us that Carbide is coming out with everything they have. It will help our lawyers."

India is suing Union carbide for $\$ 3,300$ million in damages after having rejected an out of court settlement offer of $\$ 300$ 350 million. The lawsuit over the Bhopal disaster, which killed about 2,000 and injured another 200,000 , has been bogged down in the Indian courts since September 1986 when India first filed the claim.

Evidence to prove sabotage was filed by Carbide through a 160-page affidavit in the Bhopal court six months ago. According to the New York Times, the company, which is nearing the end of its 16-month investigation, has obtained new documents and witnesses including an operator who allegedly committed the sabotage. According to Carbide, the operator removed a pressure gauge connected to the MIC tank and connected a water hose. Carbide claims to have a witness who noticed the water hose and the missing pressure gauge. Other proof includes altered log books to erase evidence that addition of water was deliberate.

Carbide's legal strategy has been to avoid paying several million dollars of compensation by showing that the accident was caused by deliberate action by an employee. An Indian technical team that investigated the accident had agreed that entry of water into the MIC tank triggered the accident. But it made clear that bad design of the plant, wrong choice of materials for its construction, and inadequate provision of control and alarm systems were chiefly responsible for the accident running out of control. "We do not believe in the sabotage theory because it is impossible for a low-level operator to be clever enough to know the consequences of his act which we ourselves could determine only after weeks of analysis", said a scientist connected with the investigation.

Indian officials say they are not worried about what theory is advanced by Carbide as far as the lawsuit goes. "All we say", said an official, "is that the plant was so badly designed that conditions for the accident were inherent and extant." He likened the Carbide-managed Bhopal plant to a room with a box of explosives at a corner, a detonator in another corner, wires in between and a roof full of holes. "All conditions existed for the room to explode with the fall of a big stone over the detonator from the hole in the roof", he said. "Whether the stone was dropped accidentally or deliberately does not make any difference to our case."

K.S. Jayaraman 